\title{
KARAKTERISTIK SIFAT TANAH SEBAGAI FAKTOR PENENTU POTENSI PERTANIAN DI NAGARI SILOKEK KAWASAN GEOPARK NASIONAL
}

\author{
CHARACTERISTICS OF SOIL PROPERTIES AS DETERMINING FACTORS \\ FOR ARICULTURAL POTENTIALS IN THE VILLAGE SILOKEK OF \\ NATIONAL GEOPARK AREA \\ Riza Syofiani $^{1}$, Santi Diana Putri ${ }^{1}$, Nike Karjunita ${ }^{1}$ \\ ${ }^{1}$ Program Studi Agroteknologi, STIPER Sawahlunto Sijunjung
}

Email : rizasyofiani14@gmail.com

\begin{abstract}
Research on analyzing the characteristics of chemical and physical characteristics of soils in Village Silokek, Sijunjung National Geopark, has been carried out at the Soil Science Laboratory of the Faculty of Agriculture, Andalas University. The purposes of this study was to analyze and determine the characteristics of soil properties as a determinant of agricultural potential in the Village of Silokek the national geopark area. This research was conducted using a survey method. Samples were taken by purposive random sampling. Soil samples were taken at two depths namely $0-20 \mathrm{~cm}$ and $20-40 \mathrm{~cm}$ using a Belgie drill. Analysis of soil samples including soil texture by the Sifter and Pipette method, $\mathrm{pH}(1: 1)$ by the glass meter electrode method, N-total by the Kjedahl method, P-available by the Bray-2 method measured on a spectrophotometer, $\mathrm{K}$ which can be exchanged by the method washing with ammonium acetate $\mathrm{pH} 7$ and C-organic by the Walkey and Black method. The results showed that characteristics of the chemical properties and physical properties of the soil in Village Silokek had been low level of soil fertility. Soil $\mathrm{pH}$ at acidic criteria, total $\mathrm{N}$-content and P-available soil were at low criteria, while of K-dd with medium criteria and C-organic soil showed at very low. The soil texture in Village Silokek was at sandy clay texture class.
\end{abstract}

Keywords: soil properties, Silokek, Geopark

\begin{abstract}
ABSTRAK
Penelitian tentang analisis karakteristik sifat kimia dan fisika tanah di Nagari Silokek kawasan geopark nasional Kabupaten Sijunjung, telah dilaksanakan di Laboratorium Ilmu Tanah Fakultas Pertanian Universitas Andalas. Tujuan penelitian ini adalah untuk menganalisis dan mengetahui karakteristik sifat tanah sebagai faktor penentu potensi pertanian di Nagari Silokek kawasan geopark nasional. Penelitian ini dilakukan dengan menggunakan metode survei. Sampel diambil secara purposive random sampling. Sampel tanah diambil pada dua kedalaman yaitu $0-20 \mathrm{~cm}$ dan $20-40 \mathrm{~cm}$ dengan menggunakan bor Belgie. Analisis sampel tanah meliputi tekstur tanah dengan metode Ayak dan Pipet, pH (1:1) dengan metoda elektroda gelas $\mathrm{pH}$ meter, $\mathrm{N}$-total dengan metode Kjedahl, P-tersedia dengan metode Bray-2 diukur pada spektrofotometer, $\mathrm{K}$ yang dapat dipertukarkan dengan metode pencucian dengan amonium asetat $\mathrm{pH} 7$ dan $\mathrm{C}$-organik dengan metode Walkey and Black. Dari hasil penelitian diperoleh bahwa karakteristik sifat kimia dan sifat fisika tanah di Nagari Silokek mempunyai tingkat kesuburan tanah yang rendah. $\mathrm{pH}$ tanah berada pada kriteria
\end{abstract}


masam, kandungan N-total dan P-tersedia tanah pada kriteria rendah, sementara itu K-dd dengan kriteria sedang dan $\mathrm{C}$-organik tanah berada pada kriteria sangat remdah. Tekstur tanah di Nagari Silokek berada pada kelas tekstur pasir berlempung.

Kata kunci : sifat tanah, Silokek, Geopark

\section{PENDAHULUAN}

Nagari Silokek adalah salah satu nagari (desa) yang ada di Kecamatan Sijunjung, Kabupaten Sijunjung. Kawasan Geopark Ranah Minang Silokek merupakan suatu kawasan wisata yang objek utamanya adalah keindahan dan keunikan alam serta ditambah unsur sejarah. Kawasan ini memiliki topografi berbukit-bukit dan berlembah, memiliki keragaman geologi yang unik dan berbagai lokasi daerah yang menunjang dari faktor alamnya.

Pembangunan kawasan agribisnis berbasis pertanian merupakan salah satu alternatif program yang diharapkan dapat menjawab tantangan dan tuntutan pembangunan yaitu meningkatkan pendapatan dan kesejahteraan masyarakat di Nagari Silokek. Banyak faktor pendukung untuk menjadikan sektor pertanian di nagari ini sebagai prioritas utama, diantaranya kondisi sumber daya alam yang dilintasi oleh aliran sungai dan kondisi sumber daya manusia mayoritas bermata pencaharian sebagai petani (Badan Pusat Statistik Kabupaten Sijunjung, 2018).

Pengembangan kawasan pertanian di Nagari Silokek harus ditunjang dengan karakteristik sifat tanah yang baik. Tanah merupakan elemen dasar yang tidak terpisahkan dalam dunia pertanian. Tanah menjadi sangat penting karena tanah menyediakan unsur hara, seperti mineral, bahan organik, air dan udara bagi tumbuhan untuk proses fotosintesis (Darmawijaya, 1997) Teknik budidaya yang diterapkan pada suatu lahan sangat mempengaruhi kondisi kesuburan tanah, baik sifat kimia, fisika, maupun biologi. salah satu komponen kimia tanah yang terpengaruh yaitu unsur fosfor (P) (Rahmah, 2014). Demikian juga dengan tipe penggunaan lahan dapat berpengaruh pada tingkat kesuburan tanah baik dari sifat kimia, fisika, maupun biologi tanah.

Tanah merupakan fokus utama dalam pembahasan kesuburan tanah, sedangkan tanaman merupakan indikator utama mutu kesuburan tanah (Yuwono, 2007). Penentuan tingkat kesuburan tanah dapat dilakukan dengan melakukan analisis sifat kimia dan fisika tanah. Analisis sifat kimia tanah tersebut meliputi analisis kandungan unsur utama seperti $\mathrm{N}$ dan $\mathrm{P}$, tingkat kemasaman $(\mathrm{pH})$, kapasitas tukar kation $(\mathrm{KTK})$, kandungan bahan organik $(\mathrm{C} / \mathrm{N})$, kation basa $(\mathrm{K}, \mathrm{Ca}, \mathrm{Mg}, \mathrm{Na})$ dan kandungan asam organik (Jumin, 1998).

Berdasarkan keterangan diatas maka penentuan karakteristik sifat tanah di Nagari Silokek perlu untuk dilakukan sebagai faktor penentu potensi pertanian di Nagari Silokek. Penelitian ini bertujuan untuk menganalisis dan mengetahui karakteristik sifat tanah sebagai faktor penentu potensi pertanian di Nagari Silokek kawasan geopark nasional.

\section{BAHAN DAN METODE}

Penelitian dilakukan di lapangan dan di Laboratorium Ilmu Tanah Fakultas Pertanian Universitas Andalas. Penelitian ini dilakukan dengan menggunakan metode survei. Sampel diambil secara purposive random sampling . sampel tanah diambil pada dua kedalaman yaitu $0-20 \mathrm{~cm}$ dan 20-40 $\mathrm{cm}$ dengan menggunakan bor 
Belgie. Analisis sampel tanah meliputi tekstur tanah dengan metode Ayak dan Pipet, $\mathrm{pH}(1: 1)$ dengan metoda elektroda gelas $\mathrm{pH}$ meter, $\mathrm{N}$-total dengan metode Kjedahl, P-tersedia dengan metode Bray-2 diukur pada spektrofotometer, $\mathrm{K}$ yang dapat dipertukarkan dengan metode pencucian dengan amonium asetat $\mathrm{pH} 7$ dan C-organik dengan metode Walkey and Black.

\section{HASIL DAN PEMBAHASAN}

Tanah wilayah Nagari Silokek termasuk ordo Ultisol atau dulu dikenal dengan nama Podsolik Merah Kuning (PMK). Tanah Ultisol merupakan tanah yang telah mengalami pelapukan lanjut akibat curah hujan yang tinggi. Curah hujan yang tinggi mengakibatkan pencucian kation basa dari lapisan tanah yang lebih dalam sehingga reaksi tanah $(\mathrm{pH})$ pada daerah ini termasuk dalam kriteria masam. Tanah Ultisol dijumpai pada ketinggian antara 50-350 m dpl (Nagari Silokek berada pada ketinggian 150-200 $\mathrm{m} \mathrm{dpl)} \mathrm{dengan} \mathrm{rata-rata} \mathrm{curah}$ hujan antara 2500-3500 mm/tahun (ratarata curah hujan Nagari Silokek 1.800$2.600 \mathrm{~mm} /$ tahun).

$\begin{array}{ccc}\text { Secara alami Ultisol tergolong } \\ \text { berkesuburan } & \text { rendah, } & \text { berwarna }\end{array}$
kekuningan atau kemerahan dan memiliki berbagai masalah keharaan yang rendah pula. Kemasaman tanah dan kadar Al yang tinggi merupakan masalah utama, sedangkan hara N-total, P-tersedia dan Kdd yang rendah merupakan masalah berikutnya yang menjadi faktor pembatas bagi usaha pertanian, untuk membuktikan berbagai masalah keharaan yang ditemui pada tanah Ultisol dilakukan uji sifat kimia dan fisika tanah di Laboratorium Ilmu Tanah Universitas Andalas, Padang. Paramater yang dianalisis yaitu tingkat kemasaman atau kebasaan tanah $(\mathrm{pH})$, kandungan $\mathrm{N}$-total, kandungan $\mathrm{P}$-tersedia $\left(\mathrm{P}_{2} \mathrm{O}_{5}\right)$, kandungan K-tersedia $\left(\mathrm{K}_{2} \mathrm{O}\right)$, kandungan karbon-organik (C-organik), dan tekstur tanah. Data hasil analisis sifat kimia sampel tanah Nagari Silokek disajikan pada Tabel 1 .

Tabel 1. Ciri Kimia Tanah di Nagari Silokek

\begin{tabular}{cccccc}
\hline Kedalaman Tanah & $\mathrm{pH}$ & N-total $(\%)$ & P-tersedia $(\mathrm{ppm})$ & $\begin{array}{c}\text { K-dd } \\
(\mathrm{me} / 100 \mathrm{~g})\end{array}$ & $\begin{array}{c}\text { C-organik } \\
(\%)\end{array}$ \\
\hline $0-20 \mathrm{~cm}$ & $4,49 \mathrm{~m}$ & $0,20 \mathrm{r}$ & $13,87 \mathrm{r}$ & $0,34 \mathrm{sd}$ & $0,61 \mathrm{sr}$ \\
\hline $20-40 \mathrm{~cm}$ & $4,80 \mathrm{~m}$ & $0,15 \mathrm{r}$ & $13,40 \mathrm{r}$ & $0,35 \mathrm{sd}$ & $0,32 \mathrm{sr}$ \\
\hline
\end{tabular}

Ket: $\mathrm{m}=$ masam, $\mathrm{sr}=$ sangat rendah, $\mathrm{r}=$ rendah, $\mathrm{sd}=$ sedang

Sumber kriteria: Staf Pusat Penelitian Tanah (1983 cit Hardjowigeno,2007)

Sumber : Hasil Analisis di Laboratorium, 2019

\section{Nilai pH tanah}

Pengukuran $\mathrm{pH}$ tanah merupakan salah satu hal terpenting yang harus dilakukan untuk mengetahui kesuburan tanah. $\mathrm{pH}$ tanah di Nagari Silokek pada kedalaman $0-20 \mathrm{~cm}$ dan $20-40 \mathrm{~cm}$ berada pada kriteria masam (Tabel 1). Hal ini disebabkan karena tanah di lokasi ini terletak di daerah tropis basah dengan curah hujan yang tinggi mengakibatkan pelarutan dan penghanyutan kation-kation basa dari komplek jerapan dan yang tertinggal adalah kation-kation yang mempunyai kemampuan terikat kuat dengan koloid tanah seperti aluminium (Al). Banyaknya Al-dd yang terjerap pada permukaan koloid tanah dapat menyebabkan terjadinya hidrolisis, yang menyumbangkan ion $\mathrm{H}^{+}$dalam jumlah yang banyak, sehingga tanah bereaksi masam. Semakin banyak ion Al yang mengalami hidrolisis, semakin banyak ion $\mathrm{H}$ yang disumbangkan, dan semakin masamlah tanah tersebut atau dengan kata lain $\mathrm{pH}$ tanah akan 
semakin rendah. $\mathrm{pH}$ tanah yang rendah atau kurang dari 7 (Tabel 1) memiliki kandungan unsur hara yang rendah dan kondisi tersebut akan menyebabkan pertumbuhan dan hasil tanaman menjadi tidak optimal. Menurut Buckman and Brady (1982), tanaman membutuhkan $\mathrm{pH}$ tanah yang netral $(\mathrm{pH}=7)$ agar pertumbuhan dan hasil menjadi optimal. Pada $\mathrm{pH}$ mendekati netral, keberadaan unsur hara dalam kondisi maksimum untuk pertumbuhan tanaman.

\section{N-total tanah}

Nitrogen merupakan unsur hara utama bagi pertumbuhan tanaman. Fungsi dari unsur nitrogen pada tanaman adalah (1) meningkatkan pertumbuhan vegetatif tanaman, (2) meningkatkan kadar protein dalam tanah, (3) meningkatkan tanaman penghasil dedaunan seperti sayuran dan rerumputan ternak, (4) meningkatkan perkembang biakan mikro organisme dalam tanah, (5) berfungsi untuk sintesa asam amino dan protein dalam tanaman.

Nitrogen adalah unsur hara utama bagi pertumbuhan tanaman. Kandungan $\mathrm{N}$ total tanah pada semua kedalaman $(0-20 \mathrm{~cm}$ dan 20-40cm) di Nagari Silokek berada pada kriteria rendah (Tabel 3). Hal ini berhubungan dengan nilai $\mathrm{pH}$ tanah yang masam. Jika $\mathrm{pH}$ larutan tanah masam, maka nitrogen menjadi tidak tersedia bagi tanaman. Unsur hara $\mathrm{N}$ terdapat dalam jumlah yang sedikit pada tanah mineral. Sebagian besar unsur ini berada dalam bentuk organik, sehingga merupakan senyawa tidak larut dan tidak tersedia bagi tanaman.

\section{Kandungan P-tersedia}

Kandungan P-tersedia tanah di wilayah Nagari Silokek tergolong rendah (Tabel 1). Rendahnya kadar P-tersedia disebabkan oleh fiksasi Al dan Fe. Fiksasi tersebut disamping menyebabkan berkurangnya ketersediaan hara dalam tanah, juga menyebabkan pemupukan menjadi tidak efesien. Semakin rendah nilai $\mathrm{pH}$ tanah, semakin besar pula jumlah $\mathrm{P}$ yang diikat sehingga $P$ tidak tersedia bagi tanaman. Pernyataan ini diperkuat oleh Hardjowigeno (2003), rendahnya ketersediaan P pada Ultisoln disebabkan oleh $\mathrm{pH}$ yang bersifat masam, dan terjadunya fiksasi $\mathrm{P}$ oleh $\mathrm{Al}$ dan $\mathrm{Fe}$ yang bermuatan positif, sehingga $\mathrm{P}$ sukar tersedia bagi tanaman.

Di dalam tanah, unsur $\mathrm{P}$ (fosfor) terdapat dalam dua bentuk, yaitu fosfor organik dan fosfor anorganik. Kedua bentuk senyawa fosfor ini pada akhirnya dapat dimanfaatkan tanaman. Fosfor organik terdapat dalam bentuk persenyawaan seperti phitin, inositol dan sebagainya. Bentuk fosfor anorganik padat biasanya dibagi dalam tiga bentuk aktif dan dua bentuk dalam bentuk yang relatif tidak aktif. Bentuk-bentuk yang aktif dapat dikelompokkan menjadi fosfat yang terikat kalsium (Ca-P), fosfat yang terikat Aluminium (Al-P) dan fosfat yang terikat besi (Fe- P). Sedangkan yang tidak aktif terdiri dari P- occluded dan dalam bentuk reduktan terlarut. Bentuk yang terakhir ini dapat larut sebagian atau seluruhnya dalam keadaan tereduksi.

Bentuk-bentuk anorganik fosfor dalam tanah tergantung pada tingkat pelapukan kimia tanah. Pada tanah-tanah yang mengalami pelapukan lanjut seperti Podsolik Merah kuning sebagian besar fosfor berada dalam bentuk yang relatif tidak aktif karena terbentuknya selaput besi dan aluminium oksida. Perubahan bentuk-bentuk fosfat ditentukan oleh derajat kemasaman tanah. Semakin masam tanah, maka bentukbentuk Ca-P diubah menjadi Al-P dan Fe-P. Peranan fosfat yang terpenting bagi tanaman adalah memacu pertumbuhan akar dan pembentukan sistem perakaran serta memacu pertumbuhan generatif tanaman.

\section{Kandungan K-tersedia $\left(\mathrm{K}_{2} \mathrm{O}\right)$}

Kalium merupakan salah satu unsur hara essensial yang diperlukan tanaman. Kalium diserap tanaman dalam bentuk ion $\mathrm{K}^{+}$melalui pertukaran kation dan secara difusi. Kalium terlarut dan kalium yang dapat dipertukarkan secara langsung 
merupakan bentuk yang dapat tersedia bagi tanaman. Adanya pelepasan kalium dari sumber-sumber lainnya kemungkinan juga dapat tersedia bagi tanaman. Kandungan kalium tersedia daerah studi tergolong sedang. Rendahnya kandungan K-dd tanah ini lain disebabkan karena tanah dengan ordo Ultisol ini terletak pada daerah yang curah hujannya melebihi kebutuhan tanah dan tanaman sehingga air yang berlebih akan membawa hanyut basa-basa yang terlarut.

Tanah ini berkembang dari bahan induk yang miskin akan kalium yang berasal dari bahan induk endapan liat. Rendahnya kandungan $\mathrm{K}$-tersedia pada tanah ini berarti bahwa potensi ketersediaan $\mathrm{K}$ pada tanah ini relatif rendah dan oleh sebab itu pemupukan kalium masih perlu dilakukan. Pemupukan perlu dilakukan karena kalium mempunyai peran yang tidak kalah penting dengan unsur $\mathrm{N}$ dan $\mathrm{P}$, kalium berperan meningkatkan resistensi terhadap penyakit tertentu, dan meningkatkan pertumbuhan perakaran. Kalium cenderung menghalangi kerebahan tanaman dan melawan efek buruk akibat pemberian nitrogen yang berlebihan, dan berpengaruh mencegah kematangan yang dipercepat oleh hara fosfor.

\section{Kandungan C-organik}

Bahan organik berasal dari hasil dekomposisi secara biologis sisa-sisa jaringan tanaman dan binatang di dalam tanah. Kandungan bahan organik tanah ditentukan dengan cara mengukur kandungan karbon (C) organik pada tanah tersebut. Kandungan C-organik tanah Nagari Silokek berada pada kriteria sangat rendah di kedua kedalaman (Tabel 1) karena tingkat pelapukan dan pembentukan Ultisol berjalan lebih cepat, iklim basah dengan suhu dan curah hujan yang tinggi menyebabkan Ultisol miskin bahan organik. Hakim et al., (1986) menjelaskan bahwa Ultisol merupakan tanah yang terbentuk di daerah tropis basah dengan curah hujan dan suhu yang tinggi sehingga pelapukan dan perkembangan tanah akan berlangsung cepat, menyebabkan pencucian kation-kation basa yang intensif sehingga kandungan $\mathrm{Al}$ tinggi dan kandungan hara akan rendah.

$$
\text { Kandungan C-organik }
$$
mempengaruhi tinggi rendahnya akumulasi bahan organik di permukaan tanah. Dodik (2009), menyatakan bahwa, bahan organik merupakan bahan penting dalam menciptakan kesuburan tanah baik secara fisik, kimia, maupun biologi. Perbedaan kondisi topografi dapat mempengaruhi intensitas proses oksidasi bahan organik di permukaan tanah. Variasi kandungan $\mathrm{C}$ organik di dalam tanah dapat berpengaruh pada pertumbuhan tanaman di atasnya. Menurut Alexander (1977) dan Stevenson (1982) bahan organik mempengaruhi pertumbuhan tanaman melalui pengaruhnya terhadap sifat fisik, kimia dan biologi tanah.

\section{Tekstur Tanah}

Uji sifat fisika tanah yang dilakukan di laboratorium adalah analisis tekstur tanah. Tekstur tanah merupakan perbandingan kandungan partikel tanah yang terdiri dari pasir, debu dan liat. Setiap lokasi memiliki jenis tekstur tanah yang berbeda tergantung dari persentase kandungan partikel tanah. Persentase kandungan partikel tanah pada Nagari Silokek dapat dilihat pada Gambar 1.

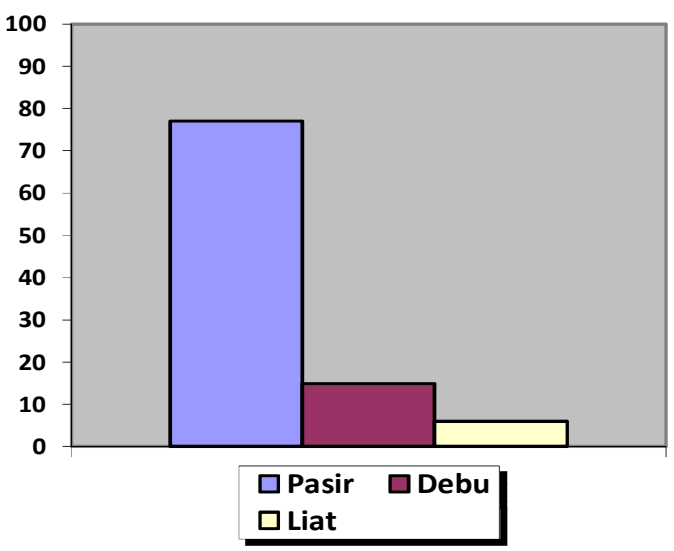

Gambar 1.

Persentase Kandungan Pasir, Debu dan Liat 
Berdasarkan persentase kandungan pasir, debu dan liat, tekstur tanah di Nagari Silokek berada pada kelas tekstur pasir berlempung. Tanah lapisan atas pasir, sehingga perbandingan fraksi pasir, debu dan liat tidak berimbang karena didominasi pasir. Tanah yang lebih didominasi oleh fraksi pasir akan memudahkan akar tanaman untuk berpenetrasi akan tetapi tanah menjadi lebih porus atau lebih mudah dalam meloloskan air serta memiliki ketersediaan hara yang rendah, sebaliknya bila tanah didominasi oleh fraksi liat maka akan mempersulit akar tanaman untuk berpenetrasi tetapi tanah semakin tidak porus. Menurut Hardjowigeno (2007), tanahtanah berpasir mempunyai masalah antara lain; 1) strukturnya jelek, 2) berbutir tunggal lepas, 3) mempunyai berat volume tinggi, 4) kemampuan menyerap dan menyimpan air yang rendah sehingga kurang memadai untuk mendukung usaha bercocok tanam, terutama di musim kemarau dan 5) peka terhadap pencucian unsur-unsur hara, serta sangat peka terhadap erosi.

\section{KESIMPULAN}

Berdasarkan uraian tentang karakteristik sifat kimia dan sifat fisika tanah di atas, tanah di Nagari Silokek memiliki tingkat kesuburan tanah yang rendah sehingga pertumbuhan tanaman menjadi kurang baik. Oleh karena itu diperlukan perbaikan kondisi kesuburan tanah terlebih dahulu agar tanaman dapat tumbuh dengan baik dan pemupukan menjadi efisien.

\section{DAFTAR PUSTAKA}

Alexander, M. 1977. Introduction to Soil Eastern

Microbiology (2th Ed.). Wiley

Bombay-

Limited. New Delhi-BangaloreCalcutta. 467p.

Badan Pusat Statistik Kabupaten Sijunjung. 2018. Kabupaten Sijunjung dalam Angka Tahun 2018. BPS Kabupaten Sijunjung, Sijunjung.
Buckman, H.O. dan N.C. Brady. 1982. Ilmu Tanah. Bhratara Karya Aksara. Jakarta. 788 hal.

Darmawijaya. 1997. Klasifikasi Tanah. UGM Press: Yogyakarta

Dodik, 2009. Pengukuran kandungan bahan organik dan $\mathrm{pH}$ Tanah. Diambil dari (http://dodikfaperta.blogspot.com) [21/02/2013].

Hakim, N., Nyakpa dan Lubis, A. M. 1986. Dasar-dasar Ilmu Tanah. Universitas Lampung

Hardjowigeno, S. 2003. Klasifikasi Tanah dan Pedogenesis. Jakarta : Akademika Pressindo. 250 hal.

Hardjowigeno, S. 2007. Ilmu Tanah. Akapress. Jakarta.

Jumin, H. B. 1998 Agronomi. Raja Grafindo Persada. Jakarta.

Rahmah, S., Yusran , Dan H. Umar, 2014, Sifat Kimia Tanah Pada Berbagai Tipe Penggunaan Lahan Di Desa Bobo Kecamatan Palolo Kabupaten Sigi Warta Rimba Vol. 2, No.1, Hal: 88-95, Juni 2014, ISSN: 2406-8373

Stevenson F.J. 1982. Humus chemistry genesis, composition, reactions. Willey Interscience, New York 